\title{
Archeologický výzkum slavkovské šibenice u Křenovic
}

\author{
Josef Unger \\ Ústav antropologie, Přírodovědecká fakulta Masarykovy univerzity; Kotlářská 267/2, 61137 Brno \\ Do redakce doručeno 10. dubna 2017; k publikaci přijato 6. listopadu 2017
}

\section{ARCHAEOLOGICAL RESEARCH OF THE SLAVKOV GALLOWS (NEAR THE KŘENOVICE MUNICIPALITY)}

\begin{abstract}
The Slavkov (Austerlitz) gallows was located on a well visible spot at the boundary of the Slavkov and Křenovice estates. Excavation in the area in question revealed the foundation outline of a slightly trapezoidal building made of stones. The outer length of its side measured approximately 6 meters. Within the building layers of detritus were uncovered, at places interspersed with humus-like interlayer containing numerous human bones, placed in non-anatomical positions. According to various typological patterns the Slavkov gallows belongs to the well type gallows with quadrangular foundation; this type was built from the $16^{\text {th }}$ century onward. During excavation of the gallows site infrequent fragments of ceramics were found, the majority of which can be dated to the $17^{\text {th }}$ and $18^{\text {th }}$ century. Small clips consisting a wire hook and loop which were found within the gallows area were a common part of contemporary garments. Nails, a horseshoe and metal circle were associated with traffic at the location. Two glass fragments originate from bottles which can be dated to the second half of the $17^{\text {th }}$ century up to the first half of the $18^{\text {th }}$ century. A silver coin - greschl, discovered in close surroundings, was minted in the year 1696 in the Silesian principality of Württemberg - Olešnice by the duke Christian Ulrich (1664-1704). After the excavation was concluded, the location was arranged in a form of a memorial associated with an educational footpath which reminds of the gallows existence.
\end{abstract}

\section{KEY WORDS the judiciary; gallows; modern age; archaeology}

ABSTRAKT Slavkovská šibenice byla umístěna na dobře viditelném místě na rozhraní slavkovského a křenovického katastru. Na zkoumané ploše se podařilo vypreparovat půdorys zděné stavby mírně lichoběžníkového tvaru o vnější délce stran přibližně $6 \mathrm{~m}$. Uvnitř stavby se nacházely vrstvy suti, místy proložené humusovitou mezivrstvou s četnými lidskými kostmi v neanatomické poloze. Podle různých typologických schémat se jednalo o šibenici studničního typu na čtyřbokém půdorysu, které se stavěly od 16. stol. Při odkryvu pozůstatkủ šibenice se našly nepř́liš četné zlomky keramiky především datovatelné do 17. a 18. stol. Záponky sestávající z drátěného háčku a očka, nalezené v areálu slavkovské šibenice byly běžnou součástí oděvů. Hřebíky, podkova a železný kruh souvisely s provozem na místě. Dva zlomky skla pocházejí z lahví datovatelných do druhé poloviny 17. až první poloviny 18. stol. Stř́ibrná mince - grešle, nalezená v okolí, byla ražena roku 1696 ve slezském knížectví Württemberg - Olešnice knížetem Christianem Ulrichem (1664-1704). Po skončení výzkumu bylo místo upraveno na památník související s naučnou cestou, připomínající existenci šibenice.

KLÍČOVÁ SLOVA justice; šibenice; novověk; archeologie

Šibenice patřily v minulosti k výrazným krajinným dominantám, které však od konce 18. století postupně mizely tak, že až do současnosti nezůstala na Moravě v původní podobě žádná. Jejich evidence a památková ochrana, jako dokladů hrdelního práva, se jeví jako velmi potřebná a stala se jedním z témat, kterými se zabývá Ústav antropologie Př́rodovědecké fakulty Masarykovy univerzity. Dosud byly publikovány a pro památkovou péči navrženy šibenice u Tišnova, Lomnice a Šatova
(Havlát 2015, Pěnička 2014, Unger 2014, 2015, 2016; Virdzeková 2016a). Další lokalitou, které byla věnována pozornost, je slavkovská šibenice, ležící na hranici slavkovského a křenovického katastru. Na její přibližnou lokalizaci upozornil již Ivan Štarha, který napsal, že slavkovská šibenice stávala při silnici mezi Slavkovem a Křenovicemi v trati „Pod spravedlností" (Štarha 2001, 86). Toto místo bylo pro umístění šibenice vhodné proto, že na ně bylo dobře vidět nejen $\mathrm{z}$ cesty 


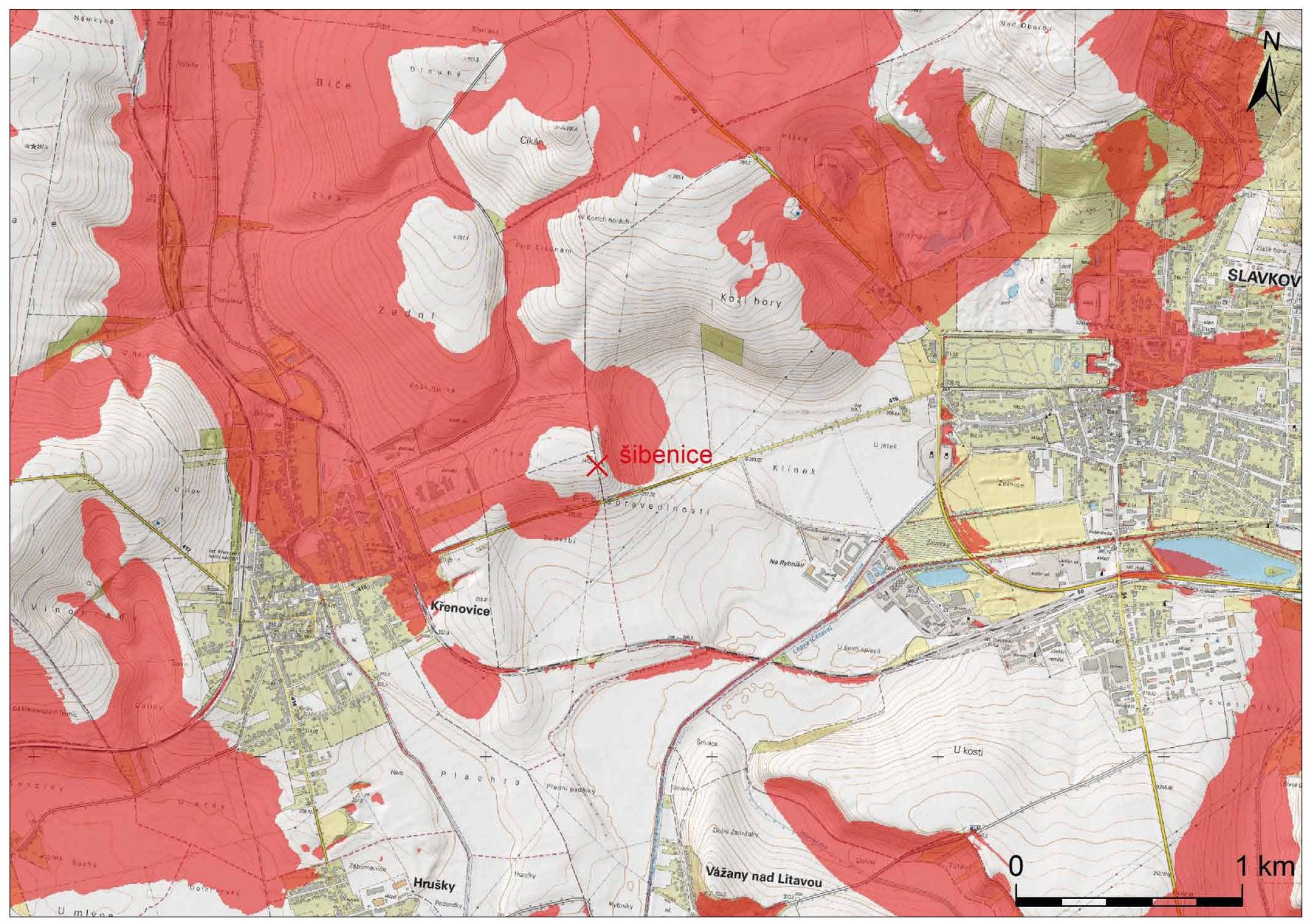

Obr. 1. Mapa viditelnosti šibenice. Zpracoval: J. Divíšek

vedoucí ze Slavkova do Křenovic a dále k Brnu, ale i z širšího okolí a tak mělo odrazovat potencionální pachatele trestních činů (obr. 1).

V letech 2015 až 2016 byl proveden plošný výzkum této lokality, který započal skrývkou na ploše 7x6,5 m jižně od nivelačního kamene. Po odstranění povrchové vrstvy se podařilo vypreparovat půdorys stavby mírně lichoběžníkového tvaru o vnější délce stran 593, 597, 587 a $585 \mathrm{~cm}$. Půdorys je vytvořen sutí (4) sestávající z úlomků hornin, malty, úlomků i celých kusů cihel a ojedinělých lidských kostí, která se odlišuje od černé humusovité hlíny na vnější i vnitřní straně. Šíŕka suti se pohybuje v rozmezí 90 až $105 \mathrm{~cm}$ (obr. 2, 3). Na západní straně byl sutový negativ proříznut sondou až na základovou spáru, která se nachází $60 \mathrm{~cm}$ pod úrovní původního terénu. Uvnitř stavby se nacházely vrstvy suti, místy proložené humusovitou mezivrstvou s četnými lidskými kostmi v neanatomické poloze (obr. 4, 5). Na třech místech bylo patrné zahloubení do původního terénu ve formě jam oválného půdorysu. Jáma 1 o rozměrech $130 \times 70 \mathrm{~cm}$ a hloubce $15 \mathrm{~cm}$, obsahovala větší množství lidských kostí včetně lebek. Jáma 2 o rozměrech $140 \times 60 \mathrm{~cm}$ a hloubce $10 \mathrm{~cm}$, byla vyplněna sutí a lidskými kostmi. Jáma 3, situovaná těsně vedle suti na severní straně, měla protáhlý oválný půdorys o rozměrech $175 \times 40 \mathrm{~cm}$ a hloubce $45 \mathrm{~cm}$, byla na povrchu překryta plochým kamenem. Pod kamenem se nacházela sut s lidskými kostmi.

Objevená situace byla písemně, kresebně i fotograficky dokumentována a potom předána obci Křenovice s doporučením, aby originální sutový negativ byl překryt geotextilií a půdorys vyznačen nízkou zídkou. Relativní nivelace byla provedena vůči nivelačnímu bodu 245,9 m nm.

V okolí šibenice byl proveden detektorový průzkum, při němž J. Havlát asi $20 \mathrm{~m}$ od šibenice našel stř́brnou minci (obr. 6), v areálu šibenice např́íklad šatní spínadla (obr. 7) a v okolí šibenice další kovové předměty.

Archeologickým výzkumem se podařilo odkrýt pozůstatky šibenice postavené $\mathrm{z}$ kamene na maltu $\mathrm{v}$ podstatě čtvercového půdorysu o vnějších rozměrech $6 \times 6 \mathrm{~m} \mathrm{~s}$ menšími odchylkami. Podle různých typologických schémat se jednalo o šibenici studničního typu na čtyřbokém půdorysu, které se stavěly od 16. stol. Na Moravě jsou časté šibenice na čtvercovém půdorysu, kdežto v Čechách a ve Slezsku jsou časté šibenice na půdorysu kruhovém (Wojtucki 2005, 27-30; Krabath 2008, 157-164; Evers 2008, 448-455; Virdzeková 2016, 15). Šibenice byla postavena $\mathrm{z}$ kamene $\mathrm{s}$ použitím cihel o rozměrech $27,5 \times 13-13,5 \times 6,5 \mathrm{~cm}$. Zdi měly šírku 90 až $100 \mathrm{~cm}$ a byly zahloubeny $60 \mathrm{~cm}$ pod povrch. Nadzemní část lze s ohledem 


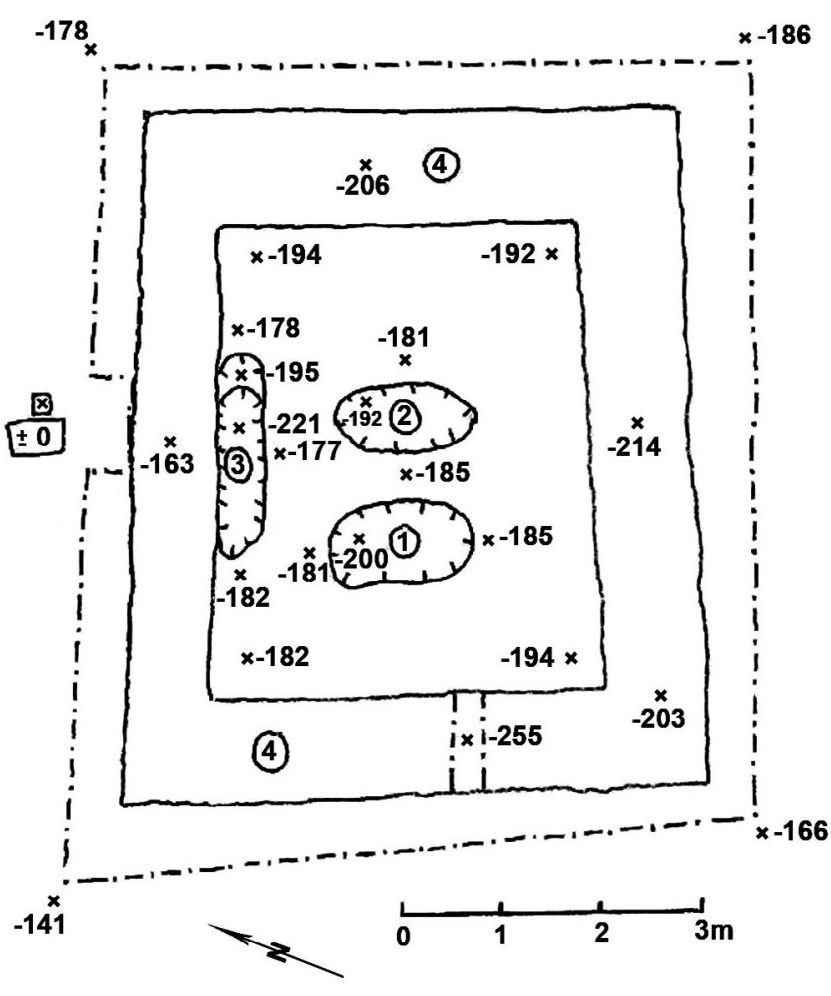

Obr. 2. Celková situace šibenice. Kresba: J. Velek

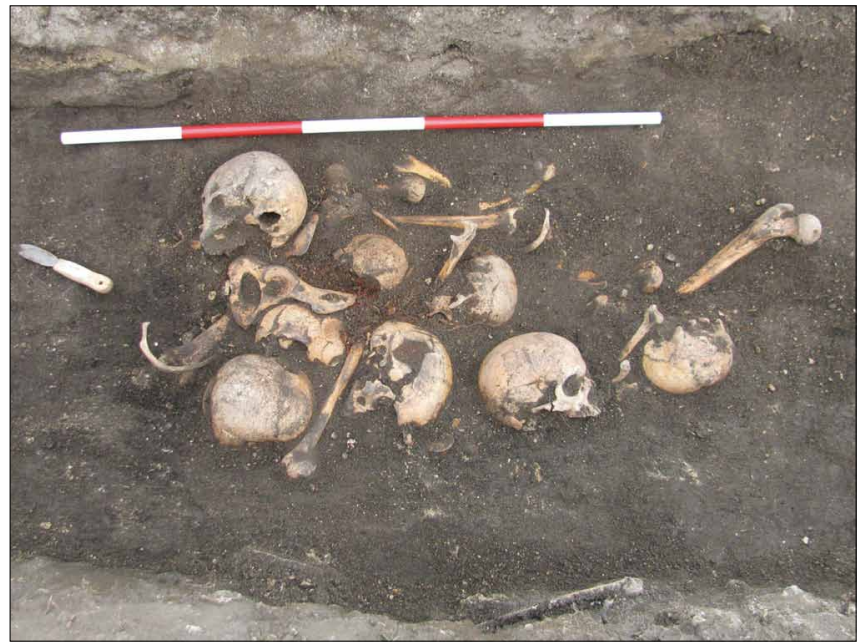

Obr. 4. Shluk kostí v interiéru šibenice. Foto: J. Unger

na dobová vyobrazení rekonstruovat tak, že nad základy bylo vyzdviženo zdivo do výšky asi $2,5 \mathrm{~m}$ prolomené na jedné straně vstupem opatřeným uzamykatelnými dveřmi. $V$ rozích pak byly nad tímto zdivem vztyčeny kamenné sloupy na čtvercovém půdorysu o délce strany $90 \mathrm{~cm}$, nahoře ukončené lůžky pro dřevěná břevna spojující tyto sloupy (obr. 8). Pozůstatky těl oběšených delikventů, která se postupně rozpadala, se ukládaly uvnitř této stavby a někdy byly postupně zahrabávány do mělkých jam. Není vyloučeno, že v úrovni pat sloupů byla spodní část uzavřena dřevěnými fošnami.

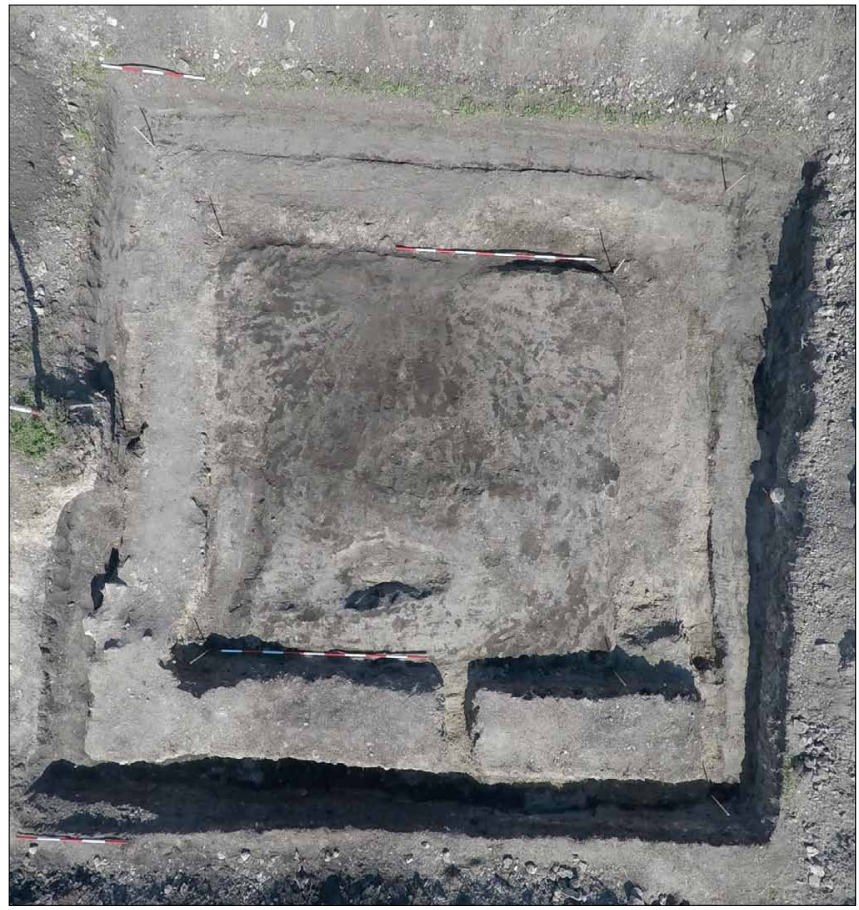

Obr. 3. Konečná fáze odkryvu šibenice. Foto: M. Daňko

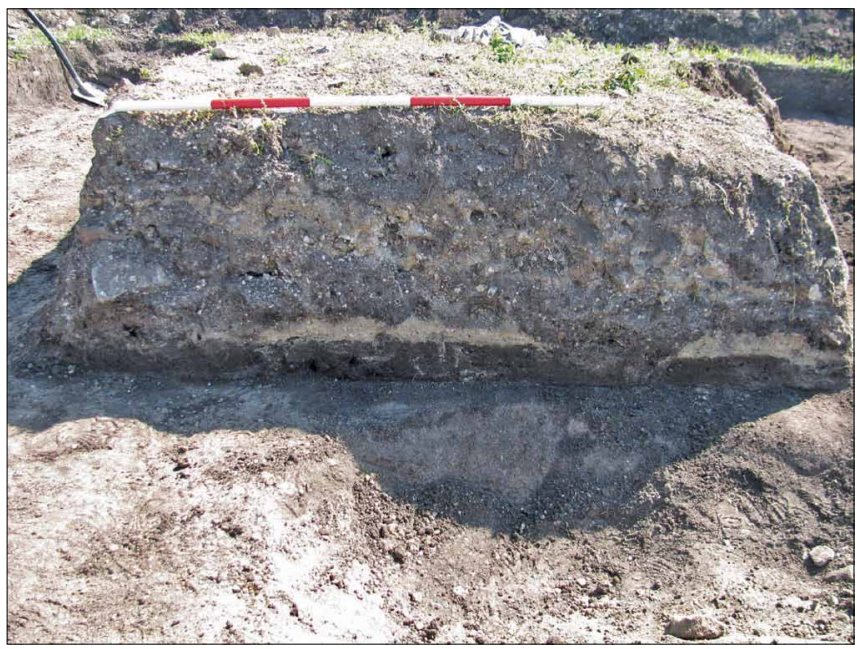

Obr. 5. Vrstvy v interiéru šibenice. Foto: J. Unger

Formát použitých cihel neodpovídá cihlám používaným na brněnském Špilberku v 16. až 19. stol. (Navrátil 2015), ani cihlovému modelu císaře Leopolda I. z roku 1686 (Holub $2011,107)$ a svědčí pro místní produkci.

Lidské i ojedinělé zviŕecí kosti se našly v neanatomické poloze (obr. 4) a jsou předmětem zvláštní studie. Zde je možno uvést, že se jednalo minimálně o 15 lidských jedinců, z čehož byl minimálně jeden ženského pohlaví. Souvisí to s dobovými zvyklostmi, že na šibenicích se popravovali především muži, a ženám býval určen jiný druh trestu smrti. Pozůstatky ženy 


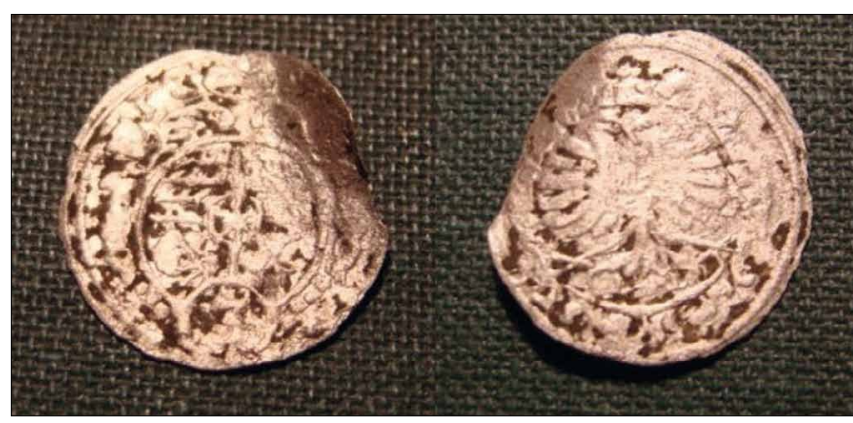

Obr. 6. Stř́brná mince - grešle ražená roku 1696 ve slezském knížectví Württemberg - Olešnice knížetem Christianem Ulrichem (1664-1704). Foto: J. Havlát

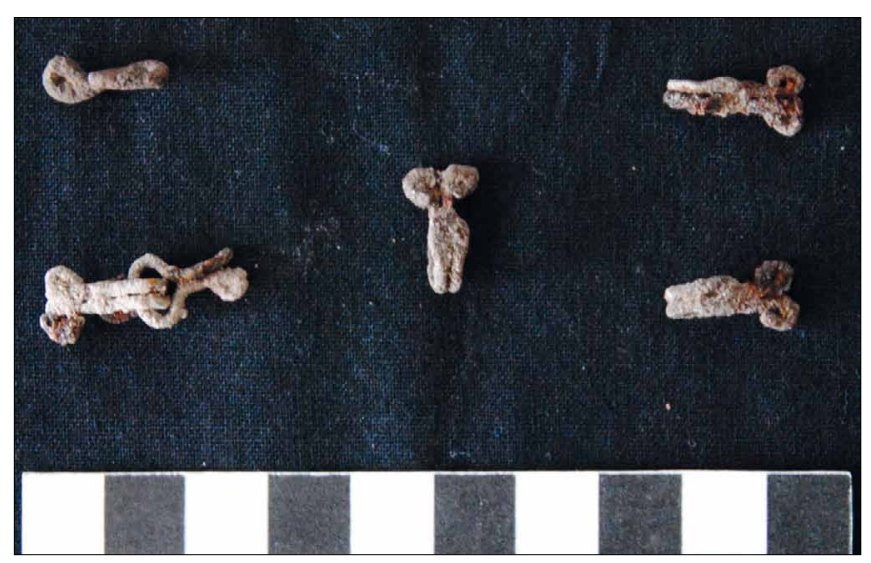

Obr. 7. Záponky nalezené v interiéru šibenice. Foto: R. Pěnička

mohou náležet popravené stětím a zahrabané uvnitř šibenice, pro což existují i písemné prameny. Při odkryvu pozůstatků šibenice se našly nepř́iliš četné zlomky keramiky. Kromě pěti zlomků, které pocházejí patrně $\mathrm{z}$ nádob pravěkého či raně stř̌edověkého stárí, jsou ostatní zlomky rámcově novověké. Podle charakteru povrchu je možno je rozdělit na nepolévané a polévané. Nepolévané zlomky patřily nejméně třem nádobám (obr. 9:4, 5). Část dna o průměru $14 \mathrm{~cm}$ a ucho oválného průřezu pocházejí asi ze džbánu zhotoveného $\mathrm{z}$ materiálu $\mathrm{s}$ prríměsí hrubší slídy a vypáleného $\mathrm{v}$ redukčním prostředí. Materiál i menší tvrdost dovolují uvažovat o časovém zařazení již do 14. až 15. stol. Jemnější materiál s příměsí jemnější slídy i tvrdé vypálení v redukčním prostředí, nasvědčují u dalších zlomků již mladšímu datování. V jednom případě se jednalo o hrnek s ovaleným a vně vyhnutým okrajem, který měl průměr $14 \mathrm{~cm}$. $\mathrm{V}$ druhém případě šlo o hrnec $\mathrm{s}$ uchem, $\mathrm{z}$ něhož se dochovalo celé dno o průměru $8,5 \mathrm{~cm}$, zlomky stěny $s$ kořenem ucha a část vně vyhnutého, ovaleného okraje $s$ dvěma žlábky na podhrdlí. Průměr okraje měřil $10,5 \mathrm{~cm}$. Výšku lze jen odhadnout na $15 \mathrm{~cm}$. Ostatní zlomky patřily asi deseti nádobám s polevou zhotoveným $\mathrm{z}$ jemně plaveného materiálu žluté až hnědé barvy (obr. 9:1-3,6). Část dna a zlomek ze stěny byly na vnitřní straně opatřeny zelenou polevou. V nalezeném souboru jsou zastoupeny části tří hrnků, či spíše hrnečků s páskovými uchy a vnitřní žlutou polevou, která částečně pokryla i povrch uch (obr. 9:3). Průměr okraje $12 \mathrm{~cm}$ se podařilo

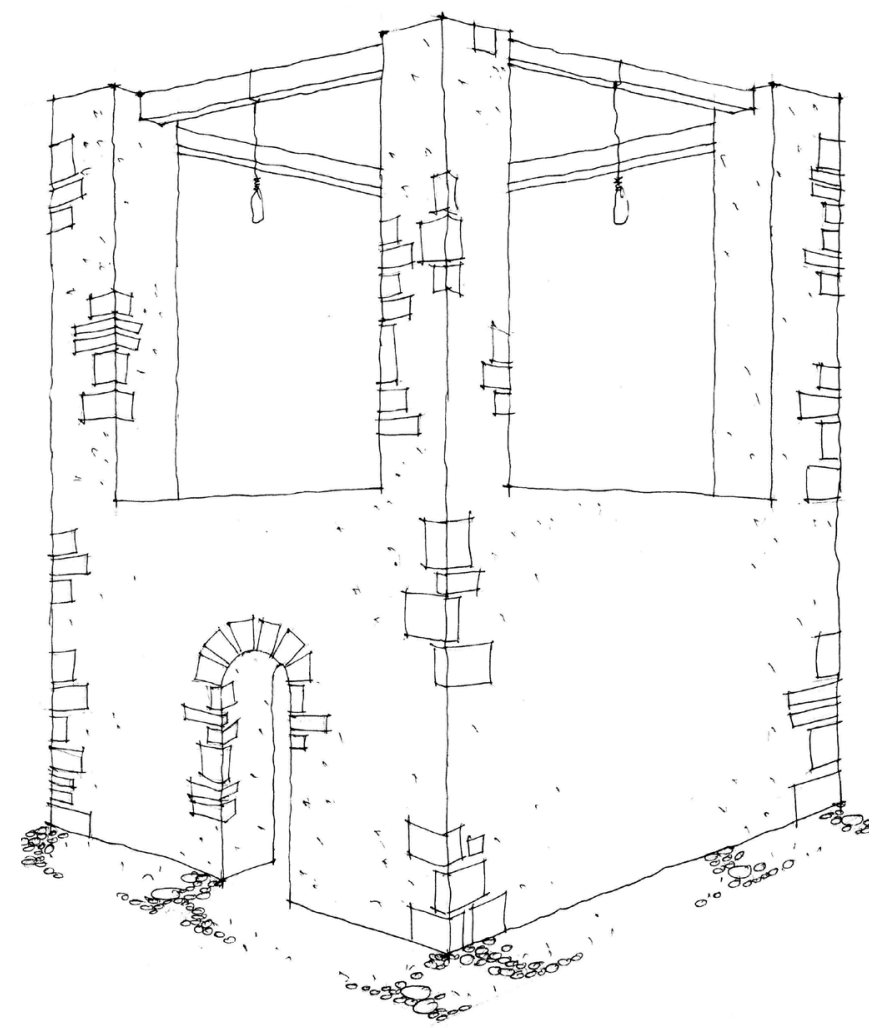

Obr. 8. Kresebná rekonstrukce vzhledu šibenice. Kresba: J. Velek

stanovit $\mathrm{u}$ jednoho exempláře a průměr den $5 \mathrm{a} 8 \mathrm{~cm} \mathrm{u}$ dvou exemplářu. Tyto nádoby bychom mohli datovat do 17. a 18 . stol., to je do doby, kdy je doloženo užívání šibenice jako místa exekucí. Zlomek plochého ucha, pokrytý na celém povrchu tmavohnědou polevou, patřil asi nádobě z 19. stol. Stejného stáří bude asi i část dna o průměru $8,5 \mathrm{~cm} \mathrm{~s}$ hnědou polevou na vnější straně a bílou polevou uvnitř. Zlomky nádob jsou poměrně častým nálezem $\mathrm{z}$ prostoru šibenic a bývají spojovány s aktivitami při budování a bourání těchto staveb (Mašková - Michálek 2006, 805, Tab. II; Sokol 2003, 745; 2016, 517; Unger 2014, 154; Wojtucki 2005, 31).

Spínadla sestávající $\mathrm{z}$ drátěného háčku a očka, nalezené v areálu slavkovské šibenice v počtu čtyř háčků a jednoho háčku s očkem (obr. 7), byly běžnou součástí oděvů od 15. stol. (Šlancarová 2016, 73). U luzernské šibenice se našly u mnoha skeletů mužů i žen (Manser 1992, 60-61). Dva hřebíky $s$ příčnou hlavicí bývaly patrně součástí konstrukce šibenice. Zahnutý hrot jednoho hřebíku svědčí o tom, že byl zatlučen do dřevěné fošny silné $7,5 \mathrm{~cm}$ (obr. 10). Podkova, $\mathrm{z}$ níž se dochovalo jen jedno rameno s hranolovým ozubem, měla původně délku jen asi $10 \mathrm{~cm}$ a byla určena pro menšího koně (obr. 10). Kruhová zděř, o vnitřním průměru $5,5 \mathrm{~cm}$, mohla sloužit k okování osy kola menšího vozu, na nějž byla fixována jedním hřebem (obr. 10).

Dva zlomky skla pocházejí z lahví. Jednak je to část dna ze čtyřboké láhve $\mathrm{z}$ nazelenalého skla, vyskytující se zhruba 

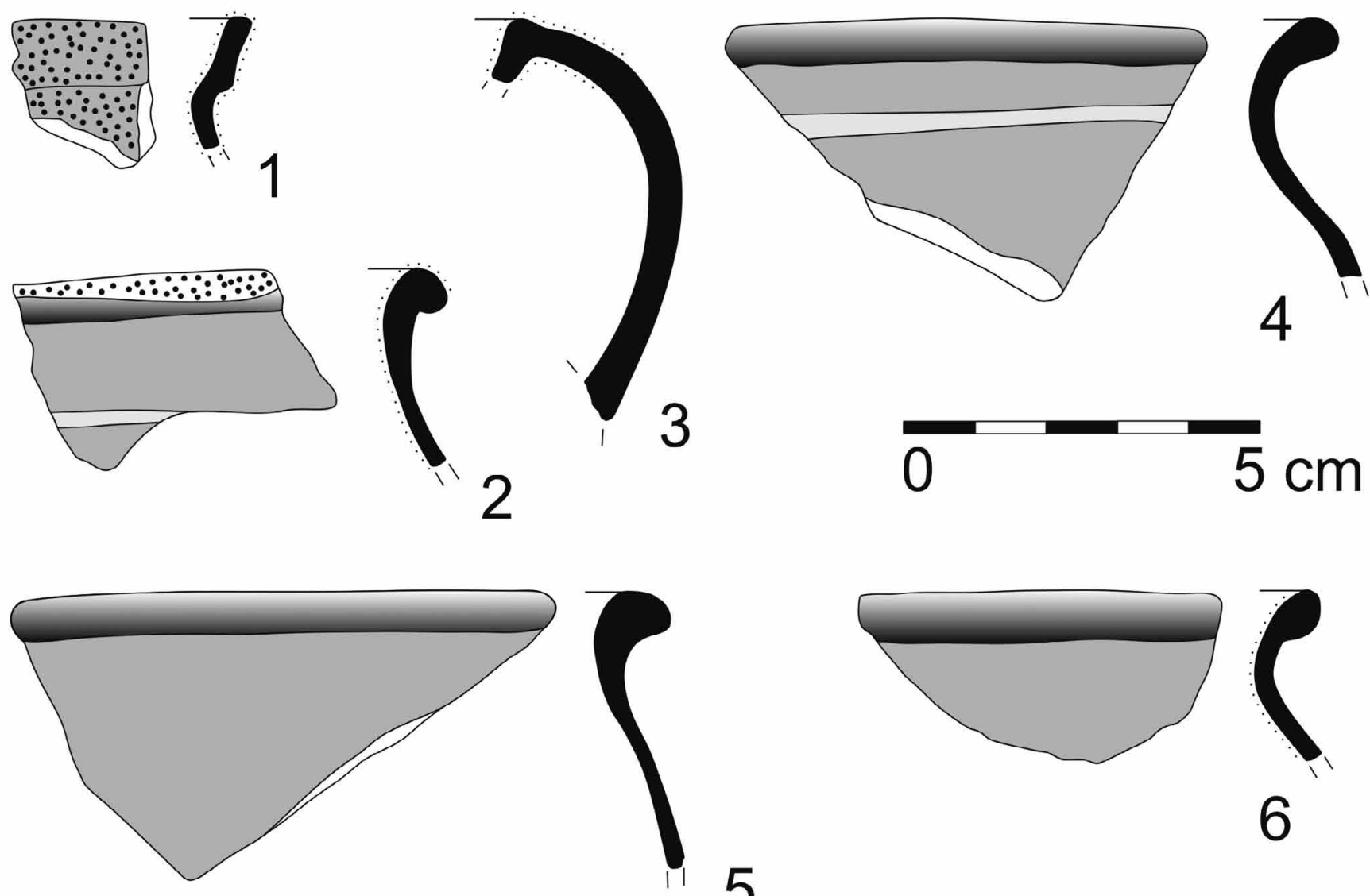

6

5

Obr. 9. Keramika nalezená v interiéru šibenice. Kresba: J. Unger a R. Knápek

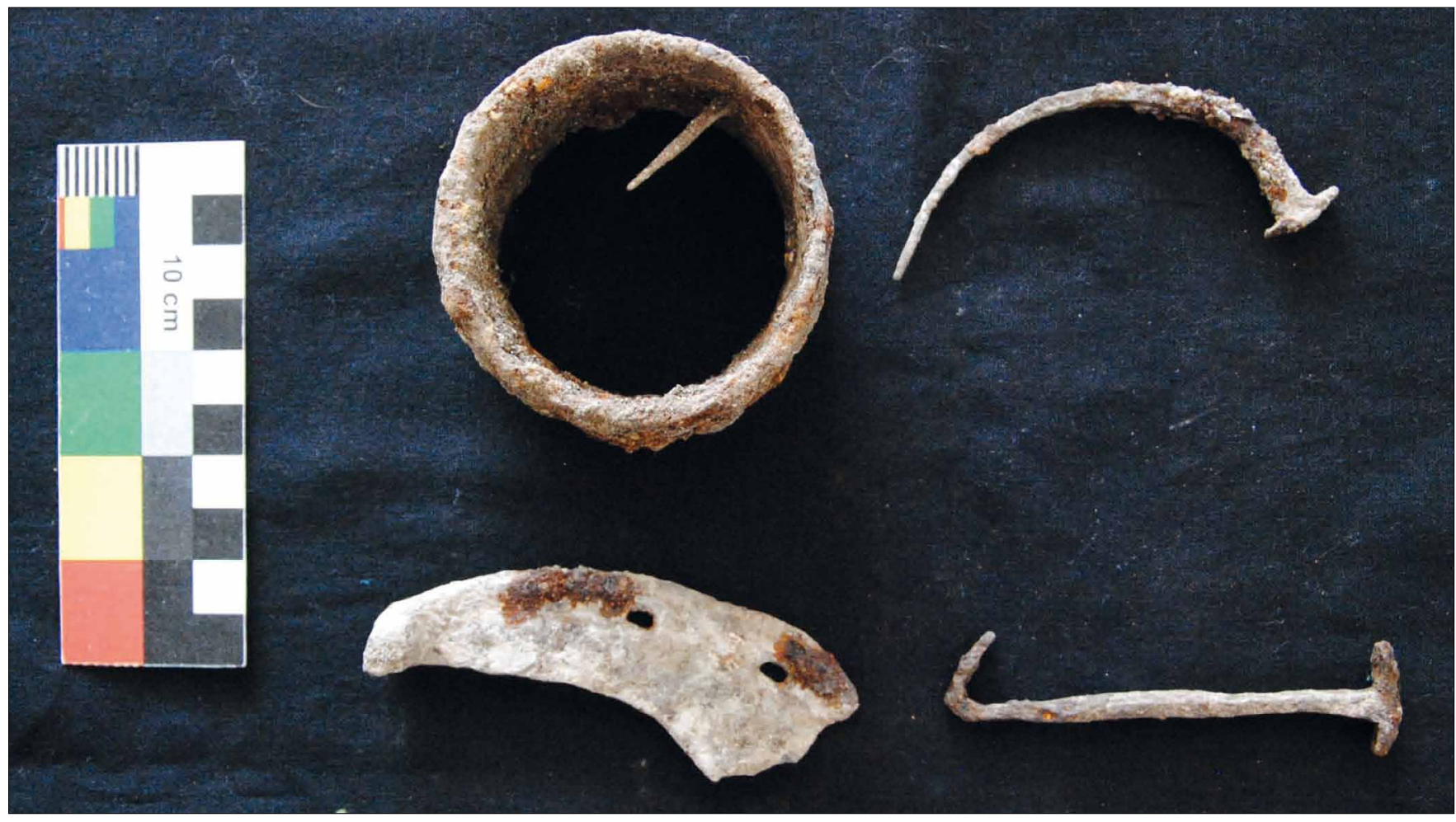

Obr. 10. Železné předměty nalezené v interiéru šibenice. Foto: R. Pěnička 


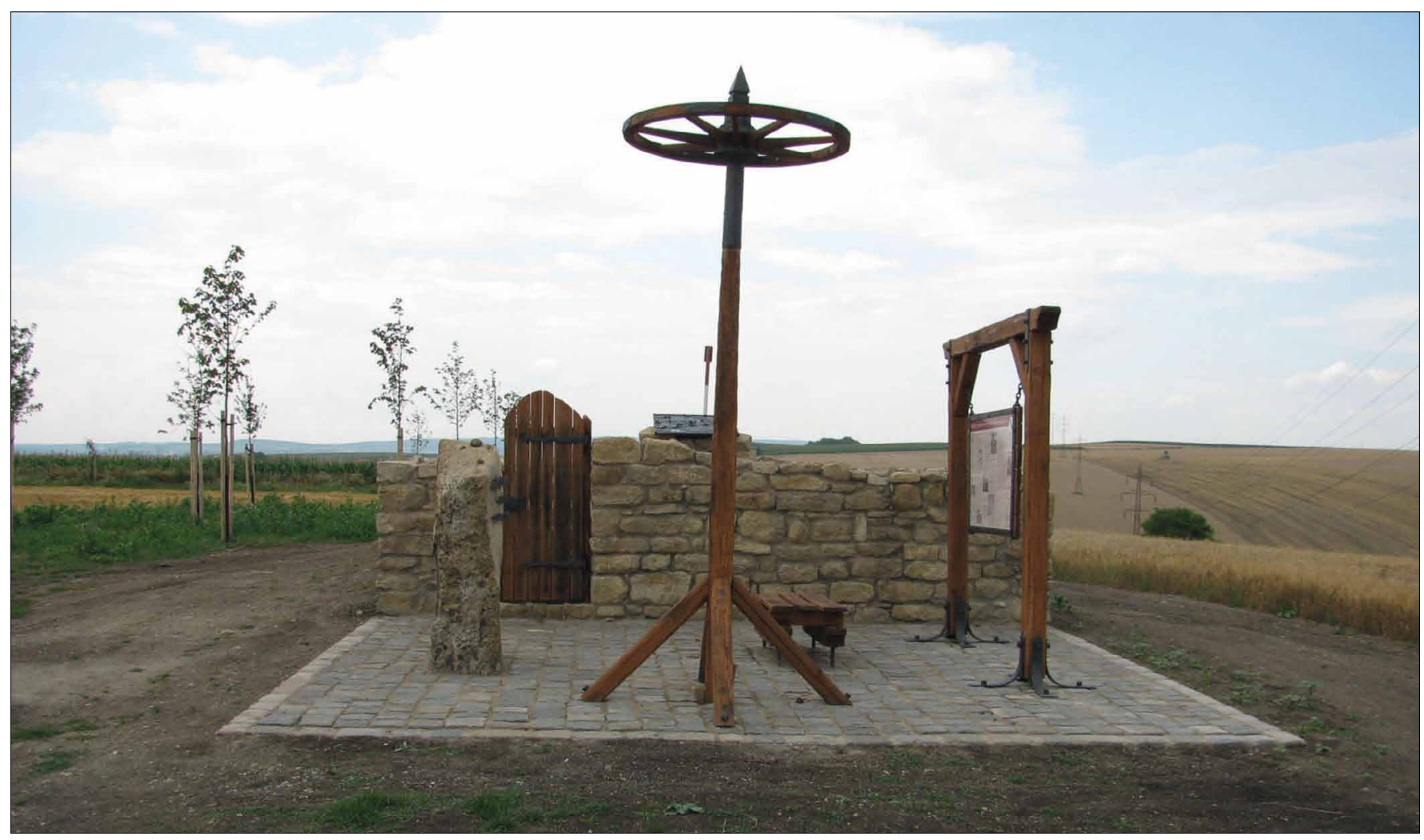

Obr. 11. Dnešní stav úpravy areálu šibenice. Foto: J. Unger

od druhé poloviny 16. do první poloviny 18. stol. V tomto př́padě se jedná asi o druhou polovinu 17. až první polovinu 18. stol. Druhý zlomek bezbarvého, nejspíše již křištálového skla, byl součástí kuželovitého hrdla láhve s válcovitým tělem, patrně z první poloviny 18. stol. (určila Hedvika Sedláčková). Jednalo se o nádobky na alkoholické nápoje, které mohly souviset s exekucí či konzumací při budování či bourání šibenice. Stř́brná mince - grešle, byla ražena roku 1696 ve slezském knížectví Württemberg - Olešnice knížetem Christianem Ulrichem (1664-1704, určil J. Havlát, obr. 6). Zřejmě byla ztracena někým $z$ davu přihlížejícího exekuci.

Po skončení výzkumu bylo místo péčí obce Křenovice upraveno na památník související s naučnou cestou, připomínající existenci šibenice (obr. 11).

Archeologickým výzkumem se podařilo odkrýt půdorys zděné šibenice s pozůstatky popravených a získat další materiál související s děním na místě. Neprokázalo se, že by místo bylo využíváno k popravám v časnějším období než 17. stol., přestože Slavkov měl mnohem starší hrdelní právo.

\section{LITERATURA}

Evers, T. (2008): Richtstätten in zeitgenössischen Bildquellen. Typologie und Topographie. In: Auler, J., ed., Richtstättenarchäologie, Dormagen, $444-465$.

Havlát, J. a kol. (2015): Cesta k tišnovské šibenici. Vlastivědný věstník moravský, LXVII, 278-285.

Holub, P. (2011): K výrobě a variabilitě stavební keramiky ve středověkém a novověkém Brně. Forum urbes medii aevi, VI, 98-121.
Krabath, S. (2008): Zwei Richtplätze in der Oberlausitz -eine seltene archäologische Denkmalgaltung. In: Auler, J., ed., Richtstättenarchäologie, Dormagen, 152-167.

Manser, J. (1992): Archäologischer Befund. In: Manser J. u. a., Richtstätte und Wasenplatz in Emmenbrücke (16.-19. Jahrhundert). Archäologische und historische Untersuchungen zur Geschichte von Strafrechtspflege und Tierhaltung in Luzern, Band 1. Basel, 39-75.

Mašková, P. - Michálek, J. (2006): Archeologický výzkum v poloze „Na šibenici“ ve Vodňanech (okres Strakonice). Př́spěvek k archeologii popravišt v Čechách. Archeologické rozhledy, LVIII, 790-809.

Navrátil, A. a kol. (2015): Stavební materiál hradu Špilberk a jeho vývoj. Archaeologia historica, 40/1, 77-87.

Pěnička, R. (2014): Kostrové nálezy a zacházení s těly zemřelých na šibenici v Tišnově. Vlastivědný věstnik moravský, LXVI SUPPLEMENTUM, 161-163.

Sokol, P. (2003): Šibenice v Bečově nad Teplou a archeologie popravišt. Archeologické rozhledy, LV, 736-766.

Sokol, P. (2016): Šibenice u Přimdy. Archeologický výzkum objektu se zvláštním symbolickým a sociálním významem. Archaeologia historica, 41(2), 501-523.

Šlancarová, V. (2016): Podoba středověkého šperku na základě jihomoravských nálezů. Disertační práce na Filozofické fakultě Masarykovy univerzity v Brně.

Štarha, I. (2001): Hrdelní soudy na Vyškovsku. Vyškovský sborník, II, 86-95.

Unger, J. (2014): Tišnovská šibenice. Vlastivědný věstník moravský, LXVI SUPPLEMENTUM, 152-160.

Unger, J. (2015): Tišnovská šibenice. In: Tauchen J. - Schelle K. a kol., ed., Trestné činy proti životu a zdraví včera a dnes. Ostrava, 191-196.

Unger, J. a kol. (2016): Lomnická šibenice. Vlastivědný věstník moravský, LXVIII, 23-29.

Virdzeková, A. (2016): Stredoveké a rano-novoveké popraviská vo svetle archeologických prameňov. Diplomová práce na Masarykově univerzitě, Brno.

Virdzeková, A. (2016a): Šatovská šibenica. Jižní Morava, 52, 399-405.

Wojtucki, D. (2005): Popraviště v Čechách a na Moravě od 16. do 19. století. In: Sborník Společnosti pro výzkum kamenných křižůi, 27-41. 


\section{AUTOR}

Unger, Josef (11. 9. 1944, Brno), archeolog a sociokulturní antropolog, profesor na Ústavu antropologie Př́rodovědecké fakulty Masarykovy univerzity. Ve výzkumné práci se zabývá především sídly a životem šlechty ve středověku, archeologií církevních objektů a antropologií pohřebního ritu. Vedl celou řadu terénních archeologických výzkumů (zaniklé vsi Topolany, Bořanovice, motte na zaniklé vsi Koválov, kostely v Mušově, Hustopečích, Brně, Tasově a na zaniklých vsích Divice, Narvice, Koválov, hrad v Lelekovicích, pohřebiště v Morkůvkách, Divákách). Člen redakční rady časopisů Castelollogica bohemica, Jižní Morava. Kromě řady odborných studií je autorem monografií, z nichž po roce 2000 vyšly: Archeologie středověku.
Odraz života lidí v archeologických pramenech (Hradec Králové 2008), Archeologie církevních památek na Moravě a ve Slezsku (Opava 2008), Religious Architecture in the Czech Republic in the Light of Geophysical Prospection and Archaeological Excavation (spolu s Vladimírem Haškem, Oxford 2010). Pro edici Panoráma biologické a sociokulturní antropologie napsal 9. svazek Pohřební ritus a zacházenís těly zemřelých $v$ českých zemích (s analogiemi $i$ jinde $v$ Evropě) $v$ 1. - 16. století (Brno 2002) a 25. svazek Pohřební ritus 1. až 20. století v Evropě z antropologicko-archeologické perspektivy (Brno 2005).

Kontakt: Prof. PhDr. Josef Unger, CSc., Ústav antropologie Prrírodovědecké fakulty Masarykovy univerzity v Brně, Kotlářská 2, 61137 Brno, Česká republika,unger@sci.muni.cz 